\title{
Analysis of comorbidities among pregnant woman attending rural Medical College Hospital
}

\author{
Raja Sekhar Jalemu, Kasthuribai Sabbe*, Grishma Jalemu
}

Department of Obstetrics and Gynecology, Krishna Hospital Visakhapatnam, India

Received: 09 June 2019

Accepted: 09 July 2019

\section{*Correspondence:}

Dr. Kasthuribai Sabbe,

E-mail: kasbi1961@gmail.com

Copyright: (c) the author(s), publisher and licensee Medip Academy. This is an open-access article distributed under the terms of the Creative Commons Attribution Non-Commercial License, which permits unrestricted non-commercial use, distribution, and reproduction in any medium, provided the original work is properly cited.

\begin{abstract}
Background: In pregnancy Anaemia and Depression is an important factor associated with an increased risk of maternal, fetal and neonatal mortality, poor pregnancy outcomes, and impaired cognitive development. To assess prevalence and factors associated with anemia and Depression among pregnant women attending antenatal clinic.

Methods: A Facility based cross-sectional study was conducted on 284 pregnant women to at Rural Medical college hospital from June to August 2018. Data on sociodemographic and clinical characteristics of the study participants were collected using a Pretested structured questionnaire by interview and review of medical records. Binary Logistic regression analysis had been used to check for association between dependent and independent variables in all cases. P-value less than 0.05 was considered statistically significant.

Results: The prevalence of anemia was found to be11.6\% (95 \%CI; 7.8\%-14.8\%) and Depression was 8.6\% Pregnant women in the second and third trimester [AOR $(95 \% \mathrm{CI}), 8.31(1.24-55.45)$, and $\mathrm{P}=0.029$ ] were more likely to be anemic when compared to pregnant women in their first trimester. Pregnant women who did not receive iron/folic acid supplementation [AOR $(95 \% \mathrm{CI}), 4.03(1.49$ 10.92), and $\mathrm{P}=0.01$ ] were more likely to be anemic when compared to pregnant to women who did take supplementations.

Conclusions: In this study the prevalence of anemia and Depression in pregnancy was low compared to the findings of others. Gestational age (trimester) and iron/folic acid supplementation were statistically associated with anemia.
\end{abstract}

Keywords: Anemia, Antenatal, Depression, Iron folic acid supplementation, Pregnancy, Prevalence

\section{INTRODUCTION}

Anemia is a decrease in the oxygen carrying capacity of the blood. It can arise if the hemoglobin $(\mathrm{Hb})$ concentration of the red blood cells (RBCs) or the packed cell volume of RBCs (PCV) is below the lower limit of the reference interval for the individual's age, gender, geographical location, and physiological status. ${ }^{1,2}$ During pregnancy the total blood volume increases by about 1.5 liter. ${ }^{3}$ The plasma volume increases more compared to red cell mass which leading to hemodilution and reduced hemoglobin concentration. This is termed physiological anemia of pregnancy. ${ }^{3,4}$ The World Health Organization
(WHO) has suggested that anemia is present in pregnancy when $\mathrm{Hb}$ level is $<11 \mathrm{~g} / \mathrm{dl}$. It also classified anemia in pregnancy as mild (10.0-10.9g/dl), moderate (7.0$9.9 \mathrm{~g} / \mathrm{dl}$ ), and severe (lower than $7.0 \mathrm{~g} / \mathrm{dl}$ ) based on the level of hemoglobin concentration. ${ }^{5}$ Anemia is a public health problem in both developed and developing countries. It affects 1.62 billion people globally, which corresponds to $24.8 \%$ of the world population. Global prevalence of anemia in pregnant women is $41.8 \%$ and the highest proportions of pregnant women affected are in Africa (57.1\%). ${ }^{5}$ Depressive symptoms during pregnancy may have devastating consequences, not only for the women, but also for the child and family. ${ }^{6}$ Antepartum 
depressive and anxiety symptoms (ADS and AAS, respectively) can lead to postpartum depression. ${ }^{7,8}$ Lower birth weight, and premature delivery, and have a negative impact on child development. So, this study was planned to estimate the prevalence of anemia and Depression in women attending ANC clinic.

\section{METHODS}

Facility Based cross sectional study. Antenatal clinic of rural Medical College and Hospital. From June to August 2018. Pregnant females attending ANC during the study period. Purposive sampling technique. The required sample size for this study was calculated using a single population proportion formula with a $95 \% \mathrm{CI}, 5 \%$ margin of error, and assumption that $21.3 \%$ of pregnant women are anemic. ${ }^{9}$ Using Formula 4PQ/L2 and $10 \%$ nonresponse rate the required sample size was 284 .

- Study tools: pretested questionnaire

- Consent type: Written Informed consent

- Ethical Consideration: The study was approved by Institutional Ethics Committee.

Interviewer administered structured pretested questionnaire and review of medical records were used to collect data on the sociodemographic characteristics, obstetric and gynecological, diet, and clinical characteristics of the study participants depression and anxiety. The interview and record review were conducted by two trained ANC service provider nurses at ANC clinic. About $4 \mathrm{ml}$ venous blood specimens were taken from each participant in K3-EDTA tubes for the hematological examinations. Automated hematology analyzer Cell-Dyn 1800 (Abbott Laboratories Diagnostics Division, USA) was used to determine complete blood count.

\section{Statistical analysis}

Data from both questioner and laboratory were checked and cleaned for completeness and consistency and then analyzed using Statistical Package for the Social Science (SPSS) Version 20 statistical software. (Trail version). Descriptive statistics such as frequency, percentage, and mean and standard deviation were used to describe dependent and independent variables. Binary logistic regression analysis had been used to check for association between dependent and independent variables. A p-value $<0.05$ is considered statistically significant.

\section{RESULTS}

As per Table 1 out of 284 pregnant females, 33 were anemic $(11.6 \%)$ while 251 were non-anemic. Similarly, $24(8.6 \%)$ were under depression during the time of pregnancy. The most common age group was found to be 20-40 years. Most of the females were educated. Nearly all came with the problem of blood loss. Iron and Folic acid supplementation was seen in all females of non- anemic but only $5 \%$ in anemic. This could be main factor for their low haemoglobin in our study.

Table 1: Socio-demographic details of the study participants $(\mathrm{N}=\mathbf{2 8 4})$.

\begin{tabular}{|lll|}
\hline Parameters & $\begin{array}{l}\text { Anemic } \\
(\mathbf{n = 3 3})\end{array}$ & $\begin{array}{l}\text { Depressed } \\
(\mathrm{n}=24)\end{array}$ \\
\hline Age $>=20$ years & 5 & 3 \\
\hline 20-40 years & 23 & 6 \\
\hline$>$ 40 years & 5 & 15 \\
\hline Educational status & & \\
\hline Educated & 2 & 7 \\
\hline Uneducated & 31 & 17 \\
\hline Trimester $1^{\text {st }}$ & 2 & 6 \\
\hline Trimester 2 & 11 & 6 \\
\hline Trimester $3^{\text {rd }}$ & 20 & 12 \\
\hline Blood loss & & \\
\hline No & 32 & 20 \\
\hline Yes & 1 & 4 \\
\hline IFA supplementation & & \\
\hline No & 17 & 12 \\
\hline Yes & 16 & 12 \\
\hline
\end{tabular}

Table 2: Prevalence of anemia and depression among pregnant females.

\begin{tabular}{|llll|}
\hline Parameters & Anemic & Depressed & p-value \\
\hline Age $>=20$ years & 5 & 3 & 0.11 \\
\hline 20-40 years & 23 & 6 & $0.001^{*}$ \\
\hline$>40$ years & 5 & 15 & 0.21 \\
\hline Educational status & & \\
\hline Educated & 2 & 7 & $0.01^{*}$ \\
\hline Uneducated & 31 & 17 & $0.01^{*}$ \\
\hline Trimester $1^{\text {st }}$ & 2 & 6 & 0.21 \\
\hline Trimester $2^{\text {nd }}$ & 11 & 6 & 0.11 \\
\hline Trimester $3^{\text {rd }}$ & 20 & 12 & $0.04^{*}$ \\
\hline Blood loss & & & \\
\hline No & 32 & 20 & $0.01^{*}$ \\
\hline Yes & 1 & 4 & 0.55 \\
\hline IFA supplementation & & \\
\hline No & 17 & 12 & 0.45 \\
\hline Yes & 16 & 12 & $0.02^{*}$ \\
\hline
\end{tabular}

$* \mathrm{p}<0.05$ is considered significant

As per Table 2 it was clear the prevalence of anemia is $11.6 \%$ and depression was $8.6 \%$. The most common age group to have anemia is $20-40$ years and in depression $>40$ years this can be due to fact that $>40$ years in nearing the retirement age. This association was significant. $(\mathrm{p}<0.05)$ Most of the pregnant female were anemic and depressed in 3rd trimester. And this association was also significant. $(\mathrm{p}<0.05)$ was nearly no blood loss in females. While IFA supplementation showed drastic changes. Around 17 females who were anemic and 12 depressed were not taking IFA. 


\section{DISCUSSION}

The prevalence of anemia in the present study was $11.6 \%$ $(95 \%$ CI;7.8\% 14.8\%).This prevalence was almost consistent with studies conducted in Awassa (15.1\%), Gondar (16.6\%), Debre Berhan (9.7\%), Sudan (10\%), Iran $(13.6 \%)$, and Nakhon Sawan, Thailand $(14.1 \%) .{ }^{10-14}$ However, our finding is much lower than studies conducted in Pakistan (90.5\%), India (87.2\%), Malaysia (57.4\%), Benin (68.3\%), Nigeria (54.5\%), Somali Region $(56.8 \%)$, Walayita Sodo (40\%), West Arsi zone (36.6\%), and north western zone of Tigray $(36.1 \%)$. Our result is also lower than results reported from Uganda (22.1\%), Southern Ethiopia (29\%), Southeast Ethiopia (27.9\%) Mekelle (19.7\%), and Addis Ababa (21.3\%). ${ }^{15-19}$

The difference may be due to geographical variation, differences in socioeconomic status, and dietary habits of the study participants. The lower finding of our study also may be due to the governments' effort to achieve Millennium Development Goals (MDGs) since improving maternal health is one of the eight MDGs and targeted to reduce the maternal mortality ratio by threequarters in 2015. Only the association of gestational age (trimester) and iron/folic acid supplementations did reach to a statistically significance level. Pregnant women in second and third trimester were more likely to be anemic when compared to pregnant women in first trimester. This might be due to the higher maternal plasma volume increments $(40-50 \%)$ relative to red cell mass $(20-30 \%)$ and accounts for the fall in hemoglobin concentration. ${ }^{18}$

The risk of developing anemia increased in pregnant women who did not receive iron supplementation during pregnancy when compared to those who received iron supplementation. This may be due to iron deficiencies developing during pregnancy because of the increased iron requirements to supply the expanding blood volume of the mother and the rapidly growing fetus and placenta.

\section{CONCLUSION}

This study has revealed that the prevalence of Anemia and Depression in pregnancy was low (11.62\%) $(8.6 \%)$ compared to the findings of other areas of India. Gestational age (trimester) and iron/folic acid supplementation were statistically associated with anemia in this study. Therefore, health education to create awareness about the importance of early booking for antenatal care are recommended to reduce anemia and counselling must be done in each session to reduce depression.

\section{Funding: No funding sources}

Conflict of interest: None declared

Ethical approval: The study was approved by the Institutional Ethics Committee

\section{REFERENCES}

1. Turgeon ML. Clinical Hematology: Theory and Procedures. Wilkins, a Wolters Kluwer business, 5th edition. Philadelphia: Lippincott Williams: 2012.

2. Rodak BF, Fritsma GA, Keohane EM. Hematology: Clinical Principles and Applications, 4th edition. Elsevier: Saunders; 2012.

3. Chandra S, Tripathi AK, Mishra S, Amzarul M, Vaish KA. Physiological changes in hematological parameters during pregnancy. Indian $\mathrm{J}$ Hematol Blood Transfusion. 2012;28(3):144-6.

4. Pavord S, Hunt B. The Obstetric Hematology Manual. Cambridge University Press, New York, NY: USA; 2018.

5. WHO. Haemoglobin concentrations for the diagnosis of anaemia and assessment of severity. Vitamin and Mineral Nutrition Information System: Geneva, World Health Organization; 2011. Available at: http://www.who.int/vmnis/indicators/haemoglobin.pdf.

6. Austin MP, Hadzi-Pavlovic D, Leader L, Saint K, Parker G: Maternal trait anxiety, depression and life event stress in pregnancy: relationships with infants temperament. Early Hum Dev. 2005;81:183-90.

7. Huizink AC, Mulder EJH, Robels de Medina PG, Visser GHA, Buitelaar JK: Is pregnancy anxiety a distinctive syndrome? Early Hum Dev. 2004;79:8191.

8. Bennett HA, Einarson A, Taddio A, Koren G, Einarson TR. Prevalence of depression during pregnancy: systematic review. Obstet Gynecol. 2004;103:698-708.

9. Jufar AH, Zewde T. Prevalence of anemia among pregnant women attending antenatalcare atTikur Anbessa Specialized Hospital. J Hematol Thromboembol Dis. 2014;2(1):1-6.

10. Yohannes Abere FA. Pregnancy Anaemia Prevalence and Associated Factors among Women Attending Ante Natal Care in North Shoa Zone, Ethiopia. Reprod System Sexual Dis. 2014;3(3).

11. Melku M, Addis Z, Alem M, Enawgaw B. Prevalence and predictors of maternal anemia during pregnancy in Gondar, Northwest Ethiopia: an institutional based cross-sec-tionalstudy. Anemia. 2014:ArticleID108593.

12. Abdelgader EA, Diab TA, Kordofani AA, Abdalla SE. Hemoglobin level, RBCs Indices, and iron status in pregnant females in Sudan. Basic Res J Med Clin Sci. 2014;3(2):8-13.

13. Barooti E, Rezazadehkermani M, Sadeghirad B, Motaghipisheh S, Tayeri S, Arabi M. Prevalence of iron deficiency anemia among Iranian pregnant women; a systematic review and meta-analysis. J Repro Infert. 2010;11(1):17-24.

14. Sukrat B, Suwathanapisate P, Siritawee S, Poungthong T, Phupongpankul K. The prevalenceof iron deficiency Anemia in pregnant women in Nakhonsawan, Thailand. J Med Asso Thailand. 2010;93(7):765-70. 
15. Lokare P, Gattani P, Karanjekar V, Kulkarni A. A study of prevalence of anemia and sociodemographic factors associated with anemia among pregnant women in Aurangabad city, India. Annal Nigerian Med. 2012;6(1):30.

16. Nik RN, Mohd NS, Ismail IM. The rate and risk factors for anemia among pregnant mothers in jerteh Terengganu, Malaysia. J Comm Med Health Edu. 2012;2(1):2161-0711.

17. Baig-Ansari N, Badruddin SH, Karmaliani R. Anemia prevalence and risk factors in pregnant women in anurban area of Pakistan. Food Nut Bullet. 2008;29(2):132-9.

18. Ouédraogo S, Koura GK, Accrombessi MMK, Bodeau-Livinec F, Massougbodji A, Cot M. Maternal anemia at first antenatal visit: Prevalenc eand risk factors in a malaria-endemic area in Benin. The Am J Tropical Med Hygiene. 2012;87(3):41824.

19. Olatunbosun OA, Abasiattai AM, Bassey EA, James RS, Ibanga G, Morgan A. Prevalence of anaemia among pregnant women at booking in the University of Uyo teaching hospital, Uyo, Nigeria. BioMed Res Int. 2014;rticle ID 849080.

Cite this article as: Jalemu RS, Sabbe K, Jalemu G. Analysis of comorbidities among pregnant woman attending rural Medical College Hospital. Int J Reprod Contracept Obstet Gynecol 2019;8:3264-7. 